\title{
Personal Finance Knowlegde and Practice: An Opinion Survey with Employed and Self-employed People in Pokhara
}

\author{
Puspa Raj Sharma, PhD \\ Yub Raj Bohora
}

\begin{abstract}
The ability to manage personal finances has become increasingly important in today's world. People must plan for long - term investments for their retirement and children's education. They must also decide on short-term savings and borrowing for daily life like a down payment for a house, a car loan, and other big-ticket items. Additionally, they must manage their different risk and insurance needs. This is might be the first survey about 'Personal Financial Knowledge and Practice' survey was conducted in 2011 with employed and Self-Employed people in Pokhara, Nepal. The survey revealed encouraging findings about how Employed and Self-Employed people of Pokhara approach money matters. This Personal financial literacy modeling research has been attempted to measure the literacy of Personal Finance with respect to their financial knowledge of different financial instrument and their practice or investment decisions. This study is based on stratified random sampling method with the help of financial literacy related parameters. This study has the intention to explore the skills of financial literacy; hence the objective was to test the basic financial knowledge of key products that is common to current society. In general, both categories have fairly healthy attitudes towards basic money management, financial planning and investment matters. Minorities of respondents of both catagories save, monitor their spending and are generally responsible in the use of credit. Most of the respondents recognize the importance of financial planning and have done some basic financial planning.
\end{abstract}

Keywords: personal finance, components, monitoring, planning, investing

\section{Introduction}

Personal finance is the application of the principles of finance to the monetary decisions of an individual or family unit. It addresses the ways in which individuals or families obtain, budget, save, and spend monetary resources over time, taking into account various financial risks and future life events( Debelle,. Components of personal finance might include checking and savings accounts, credit cards and consumer loans, investments 
in the stock market, retirement plans, social security benefits, insurance policies, and income tax management. Finance is a general word, which really means the matters of money. Money, of course, is a key social-economic indicator of well being that individuals look forward to in all cultures. In a sense of well being, of course, human immediate needs of having food, and clothing, and shelter are most important but what defines quality of life beyond having food, shelter and clothing is having monies or people financial affairs in order so that we can get a better standard of life. Of course, when we do so, we can increase our standard of living and this is the basic difference in societies around the world. The better understanding we have of financial terms, normally, the better standard of living we will have. In general term finance means management of money for our expenses. In broad term finance is the science of funds management. Finance includes saving money and often includes lending money. Finance is also a money budget management. The field of finance deals with how money is spent and budgeted. It also deals the concepts of time, money and risk and how they are interrelated. Finance is used by individuals as personal finance, by governments as public finance, by businesses as corporate finance, as well as by a wide variety of organizations including schools and non-profit organizations. Finance is the need of the today world economy. Finance addresses the ways in which individuals, business entities and other organizations allocate and use monetary resources over time.

Finance is also process of raising funds or capital for any kind of expenditure. Consumers, business firms, and governments often do not have the funds they need to make purchases or conduct their operations, while savers and investors have funds that could earn interest or dividends if put to productive use. Finance is the process of channeling funds from savers to users in the form of credit, loans, or invested capital through agencies including commercial banks, savings and loan associations, and such nonbank organizations as credit unions and investment companies finance. All three involve generating budgets and managing funds for the optimum results. See also corporate finance (Britannica Concise Encyclopedia).

The following are the area of finance of finance which presents the general knowledge of finance.

- Personal finance

- Corporate finance or Business finance

- Public finance

Personal finance is the application of the principles of finance to the monetary decisions of an individual or family unit. It addresses the ways in which individuals or 
families obtain, budget, save, and spend monetary resources over time, taking into account various financial risks and future life events. In this, finance decisions may involve paying for education, financing durable goods such as real estate and cars, buying insurance, e.g. health and property insurance, investing and saving for retirement. Personal financial decisions may also involve paying for a loan, or debt obligations. Components of personal finance might include checking and savings accounts, credit cards and consumer loans, investments in the stock market, retirement plans, social security benefits, insurance policies, and income tax management (Microsoft. 2009).

Debelle (2004) focused on a key component of personal finance is financial planning, which is a dynamic process that requires regular monitoring and reevaluation. In general, it has five steps:

- Assessment: One's personal financial situation can be assessed by compiling simplified versions of financial balance sheets and income statements. A personal balance sheet lists the values of personal assets (e.g., car, house, clothes, stocks, bank account), along with personal liabilities (e.g., credit card debt, bank loan, mortgage). A personal income statement lists personal income and expenses.

- Setting goals: Two examples are "1. Retire at age 65 with a personal net worth of $\$ 1,000,000$," and, "2. Buy a house in 3 years while paying a monthly mortgage servicing cost that is no more than $25 \%$ of my gross income." Having multiple goals is common, including a mix of short term and long term goals. Setting financial goals helps to direct financial planning. Goal setting is done with an objective to meet certain financial requirements.

- Creating a plan: The financial plan details how to accomplish your goals. It could include, for example, reducing unnecessary expenses, increasing one's employment income, or investing in the stock market.

- Execution: Execution of one's personal financial plan often requires discipline and perseverance. Many people obtain assistance from professionals such as accountants, financial planners, investment advisers, and lawyers.

- Monitoring and reassessment: As time passes, one's personal financial plan must be monitored for possible adjustments or reassessments.

\section{Methodology}

The required data for the study are collected from both primary and secondary 
source data are entertained in this research work. The raw primary and secondary data are modified to some extend for the study purpose. The research is mostly based on primary data. For the purpose of the collecting primary data one set of questionnaire has been administered. For the purpose of the study, the record of the population in Pokhara municipality is taken as population of the study. Out of them 28 people who were operating their own business (Self employed) and 28 people who were job holder (Employed) are taken through stratified random sampling method.

. A survey structured questionnaire and a framework for scoring the responses to the survey questionnaire is the main source of this study. Fieldwork on a population of 80 respondents aged 20 to 60 was conducted in 2011. The survey was administered through face-to face interviews at the respondents' place of residence and office. It should, however, be noted that the research has covered only analysis of findings based on the responses of those surveyed. It does not include analysis of or comparison with findings of other research projects. The scope of the survey was also limited by the need to ensure that the survey's questionnaire was kept to a manageable length. In addition, as the survey was administered face-to-face and most Pokherali regard their financial decisions as personal matters, the survey questions were kept on broad -based.

The following are the limitations of the methodology applied:

- The study selects two different categories of respondents, stratified random sampling was used.

- Analysis of data is based on opinions of the respondents hence the reliability of the analysis depends on the reliability of opinions of the selected respondents.

- Only the people who are living in the Pokhara were taken as sample. Hence the sample may not be representative on the total population.

Only descriptive tools have been used for the analysis of the data. Inferential tools have not been used in the study.

\section{Analysis of Data}

The study has summarized the analysis parts as follows:

\subsection{Respondents Profile}

The questionnaire distributed to the respondents was devoted to obtain the information about the respondents. The number of questionnaires distributed was 80 , out of which 56 of respondents duly respond the question. 
Age Group of the Respondents: In Nepalese context, normally below 20 years people are dependent with their parents and they manage their personal finance according their parents aspiration. To identify which group of people are more responsible for the personal finance, respondents were categorized into different three categories. Out of 28 employed respondents 8 (28.57) respondents are age of 20-30 years, 10 (35.71) respondents are age of 30-40 years, 4(14.29) respondents are age of 40-50 years, and remaining 6 (21.42) are age of above 50. Similarly, out of 28 self employed respondents respondents 6 (21.42) respondents are age of 20-30 years12 (42.85) respondents are age of 30-40, 6 (21.42) respondents are age of 40-50 remaining 4(14.29) are age of above 50. It can be concluded that majority of the respondents were $20-30$ years in both categories. It means young agers are the interested people about personal finance because most of the old agers didn't want to participate to the survey.

Annual Income of Respondents: Majority of Nepalese are not well educated, even though they are operating small and medium type of business which is contributing significant input in national economy. Practically they know how to mobilize their personal property but theoretically they don't have adequate knowledge.

Majority of respondents were medium class i.e. 10 (35.71\%) respondents out of 28 employed respondents are of the annual income of Rs. 300000-400000 and in the context of self employed $12(42.85 \%)$ respondents out of 28 respondents are of the annual income of Rs. 400000-500000. Similarly, from the group of annual income under Rs. 2,00,000 are very few i.e. $2(7.14 \%)$ of employed responded about the question. But no any self employed could give the answer. $6(21.42 \%)$ of employed and 4(14.28\%) from the annual income Rs. 2, 00,000-3, 00,000 responded about the question. Same number i.e. 4(14.28\%) of both categories of annual income over Rs. 5, 00,000.

Education of Respondents: Out of 28 employed respondents, majority of respondents i.e. $20(71.42 \%)$ are incomplete higher education. Similarly, out of 28 employed respondents $2(7.14 \%)$ respondents, have passed the higher secondary and $2(7.14 \%)$ from technical education. 4(14.28\%) respondents in the same category were higher educated. Same figure and table obvious that there are no any self employed respondents were response who was below secondary level and higher education. However 10 (35.71\%), 8 (28.57\%) and 12 $(42.85 \%)$ of self employed respondents were passed +2 level passed, technical education and higher education.

Family Status of Respondents: Majority of respondents from both categories are young of age that have children under 18. Out of 56 respondents $12(42.85 \%)$ from employed and 
$14(50 \%)$ from self employed have the children under 18 which is more than $50 \%$. The equal number of respondents i.e. 6 (21.43\%) from both categories were unmarried with other family members (dependents). Very few respondents from both categories had the children over 18 and no any children and other dependents i.e. 4 (14.28\%), 2 (7.14\%) The table clearly shows that Nepali citizens cannot stay without family members that might be the reason that no any respondents were found from both categories that didn't have family members.

\subsection{Basic Money Management}

This section covers a number of aspects of basic money management including savings, spending, monitoring expenditure, and borrowings.

Purchase of Financial Products: Financial products refer to instruments that help you save, invest, get insurance or get a mortgage. These are issued by various banks, financial institutions, stock brokerages, insurance providers, credit card agencies and government sponsored entities. Financial products are categorized in terms of their type or underlying asset class, volatility, risk and return. Both the profiles that distinguish certain purchase patterns are summarized in the following table.

When deciding on whether to purchase a financial product, no any respondents get any advice from financial advisor but $42.85 \%$ of employed and $35.71 \%$ respondents relied on the recommendations of their friends or relatives. $28.57 \%$ of employed and $42.86 \%$ self employed respondents did their own comparisons among similar financial products while $14.28 \%$ and $21.43 \%$ depended on the product promotion.

Savings Patterns: Almost all the respondents indicated that they had some form of savings in the bank, including either a savings or current account, some of employed and self employed respondents indicated that they did not have any bank account. These tended to be the unemployed and retirees, or those with low household income. A quarter of the respondents held their money as fixed deposits.

A large proportion (92.85\% Self employed and 100\% employed) of respondents indicated that they saved. When asked specifically how they set aside money for their savings, more than half of the employed respondents (57.12\%) and the countable number of employed respondents $(42.85 \%)$ had indicated that they paid for their expenses first, before saving the rest. About a third (35.71\%) of employed and more than half of the self employed respondents $(57.12 \%)$ had the practice of saving a fixed amount of money from their monthly salaries, before spending the balance. Those who saved a fixed amount of 
money from their monthly salaries tended to agree with the attitude statement "I should save first, before spending the balance". Only few respondents of employed category spend all the money what they earned.

Spending Patterns: When asked how they paid for their purchase of a durable item, a significant proportion 18 (64.28\%) of employed and 14 (50\%) of self employed respondents had indicated that they used cash and would not make a purchase if they could not afford the item. Very low or 4 (14.28\%) of employed and $6(21.42 \%)$ self employed used credit cards or some form of credit facility, while another 4 (14.28\%) employed and 8(28.57) self employed had turned to installment schemes. Negligible 2 (7.14\%) of employed respondents were response other pattern of purchase.

Monitoring Expenditure: When asked how they monitored their spending, most of the respondents from both the categories indicated that they keep track of how much they spend by monitoring the balance in their bank accounts i.e. $42.85 \%$ of employed and $35.71 \%$ of self employed. Proportionately, very low number $6(21.43 \%)$ of employed and $10(35.71 \%)$ of self employed respondents tracked their bills. About a third of the respondents $10(35.71 \%)$ of employed and 8 (28.57\%) of self employed indicated that they do not keep track of their expenditure.

Reasons for Not Monitoring Expenditure: Among those who do not keep track of their spending, 6 (21.42\%) of self employed and 8 (28.57\%) of employed felt that as long as their expenditure did not exceed their income, there was no need to track their spending. About 50\% (12) employed and 50\% (14) self employed cited lack of time as the reason for not monitoring their expenses while $21.42 \%$ (6) employed and very few 2 (7.14\%) said that they had no interest in money matters or that there were too many uncertainties and therefore there was no point monitoing their expenditure. The remaining $14.28 \%$ of both category said that they did not know how to monitor their expenditure.

Loans and Borrowings: About more than half of the respondents indicated that they had some form of loans or borrowings. A very few number of employed 2 (7.14\%) and more than half of the self employed respondents $18(64.28 \%)$ were business loan. The most common loans were housing loans and car loans $(28.57 \%)$ of the employed and $4(14.28 \%)$ of the self employed were enjoying the facilities. 8 (28.57\%) of employed and only 2 (7.14\%) of the self employed respondents had a bank overdraft or a renovation loan. About one-fourth $4(14.28 \%)$ of the self employed respondents held no any loans but about half of the employed respondents $12(42.85 \%)$ were not using any types of loan.

Knowledge of Loans: The respondents who had any kind of loans $(n=56)$ were asked a 
series of questions to ascertain how much they knew about their loans.

Most of the respondents appeared to be fairly well-informed about the main features of their loans. More than 50\% of employed and self employed knew the key features of their loans such as their monthly installment, the repayment period of the loan, the amount outstanding, the interest rate on the loan and the bank they borrowed from. However, one third of the both categories of re spondents were aware of the terms and penalties applicable when refinancing or redeeming their loan.

Decision to Take up Loans: Out of 100\% sample, 37.5\% of employed and $50 \%$ of self employed respondents who had a loan indicated that they worked out how much they can afford to borrow before applying for a loan. Only a one-third of employed and one-fourth of self employed proportion ( $3 \& 3$ ) easily answered the question of such decision they claimed that they have sufficient regular income to repay the required loan. Although very few $25 \%$ of employed and $8.33 \%$ of self employed respondents took up a loan first, before they worked out how much they should set aside for repayment.

Purpose for Using Loan: For those who typically pay in full, all segments were well represented. Employed and Self employed were more likely to make minimum / partial payment for their loans.

When asked about the purpose for the use of loans, about two-third of both categories respondents i.e. $(50 \% \& 64.28 \%)$ indicated that they used it primarily to buy a particular item or service. $28.56 \%$ of employed and $14.28 \%$ of self employed took up loans for emergencies while nominal percentage $7.14 \%$ of both categories used such loans to pay off other bills / loans / credit cards.

Consequence of not Repaying Loans: The employed and self employed tended not to know of the consequences of not repaying a loan. While the majority of both categories respondents i.e. $35.71 \%$ of employed and 28.57 of self employed those with a loan was aware that they had to pay interest on the outstanding balance and other compounded penalties if they rolled over their loans, only few $7.14 \%$ of employed respondents were not aware of the consequences of not repaying their loans. About half of the respondents understood that not repaying their loans in a timely manner could lead to a bad credit report with the Credit Bureau or that not repaying their loan could lead to legal actions being taken against them.

\subsection{Financial Planning}

We explained to respondents that financial planning includes setting aside savings for their future, having a retirement plan in place, purchasing insurance policies to cover 
unexpected events, and / or investing to grow their wealth. This section investigates a wide range of issues, including starting time for planning, reasons for planning and not planning, seeking expert advice, and knowledge of life insurance. Certain issues about retirement and related funds are also discussed in this section.

Making Basic Financial Planning: While researcher asked with them about the financial planning more than $50 \%$ of the both categories of the respondents indicated that they had undertaken some basic financial planning to ensure that they could meet their future financial needs. Remaining $50 \%$ of both categories did not have any type of financial planning.

Starting Time for Planning: About a third of the respondents (33\%) began financial planning when they started work. Other significant milestones that triggered the financial planning process were after they had worked for a number of years $(7.14 \%)$, after marriage (14.28\%), during school days (7.14\%), or when they had their first child. Only a small proportion of respondents (14.28\%) started thinking about financial planning just before retirement. This is an encouraging finding as it shows that respondents, in general, have takensome steps to prepare for their family's future financial needs and their own retirement needs. When asked when they should ideally start financial planning, almost all indicated that it was important to start early. A majority felt that they should develop a financial plan once they started working ( more than $50 \%$ ) or after having worked a number of years $(13 \%) .17 \%$ felt that a person should start developing a financial plan during their school days. However, the reality is that Employed tended to start financial planning later than what they considered as ideal.

Reasons for Planning and not Planning: All respondents were asked about the reasons that would prompt them to start planning while only those who mentioned that they had not started planning were asked about the reasons for not planning.

Important Reasons for Planning: For those who had started planning, a majority indicated that it was to prepare for emergencies i.e. slightly more than one-fourth 4 (25\%) of employed and one-third of employed and about $11 \%$ (2) of employed and $25 \%$ (4) self employed respondents prepare planning to provide for dependents in the family. Less than one-fourth 2(22.22\%) of employed and none of self employed respondents felt that it was important to undertake financial planning to ensure that they had sufficient retirement funds. About 11\% (2) of self employed respondents felt that it was important to plan for their finances in order to live a life free of debt. Same proportion i.e. $25 \%$ of employed and self employed participants were told that they prepare plan to get good returns in their 
investment. A small proportion about $11 \%$ of employed respondents felt told that they make plan by the advice of their advisor.

Reasons for not Planning: For those who have yet not started financial planning, a majority cited more than one case of not making proper plan that majority of employed $35.7 \%$ of employed profile and $21.28 \%$ of self employed profile mentioned that they did not have enough money. This group of respondents generally had monthly household income of less than Rs. 400000 . About $50 \%$ of employed and $30 \%$ of self employed did not see an urgent need to plan as they felt that it was still early. This group of respondents were generally aged 30 years and below. About $60 \%$ of both categories did not undertake financial planning, as they felt that there was no point planning for the future which had too many uncertainties. A small proportion or less than (25\%) of both profile respondents who did not plan for their future felt that their pension funds and personal savings were sufficient to meet their future financial needs. Significant percentage of both categories i.e. about one third told that they don't have enough time to trace out the plan accordingly. Nominal number of respondents mentioned that they don't have enough idea about making plan; their insurance is enough and handle by family.

\subsection{Approaching Professional Advisers}

Working people were more likely to seek professional advice, while non-working people or those with low income were less likely. When asked whether they had sought professional advice, very few about $28 \%$ of employed and about $14 \%$ of self employed responded that they had approached professional advisers to help them manage their finances. Those who had sought professional advice tended to agree with the attitude statement "Advice from a professional adviser is more reliable as they are experts" and also answer correctly the knowledge quiz, "A financial adviser must explain why the investment product he is recommending is suitable for his client".

Reasons for Approaching Professional Advisers: Half of (50\%) employed and onethird (33\%) of self employed those who approached professional advisers did so because the adviser (experts) was a friend / relative. 50\% of employed and 66\% of self employed had sought professional advice because they felt that they would be getting advice from an expert.

Reasons for not Approaching Professional Advisers: About 45\% of the employed and $33 \%$ of the self employed who did not seek advice from professionals, were confident that they did not need help and could make financial decisions on their own.. More than one -fourth 
of employed and less than one-fourth of self employed felt that they did not have enough money to engage a financial adviser, while about $36 \%$ of employed and $25 \%$ of self employed respondents were uncomfortable disclosing their finances to others. Other reasons cited for not approaching a financial adviser included not knowing any good adviser about $18 \%$ in employed profile and $25 \%$ in self employed. No any respondents respond the reason, no time to look for a good adviser, seeking professional advice could be costly or is meant only for the rich (18\%) in employed respondents, and also no any respondents mention the reasonfinancial advisers tend to be aggressive and only sell products based on their commissions rather than on the clients' financial needs.

\subsection{Insurance Planning}

Insurance is defined as the equitable transfer of the risk of a loss, from one entity to another, in exchange for payment. All respondents were asked about insurance policies they bought.

More than $50 \%$ of the respondents of both categories have some form of life insurance. Nominal about less than $15 \%$ have medical insurance, while $79 \%$ of employed and $86 \%$ of self employed have some form of general insurance for their car or home. Less than $15 \%$ of the both categories respondents do not have any insurance product at all. They tended to be retirees, or those with low household income.

Knowledge of Life Insurance: More than $50 \%$ who had life insurance knew the key features of their insurance policies such as the company they bought the policy from, the amount of premiums, what the policy covers, the amount of payout and whether the bonus payouts (if any) are guaranteed. However, less than 33\% of respondents were aware of what would happen if they could not afford their premiums or if they stopped paying their premiums temporarily. An even lesser proportion (around 14\%) knew what the penalty fees and charges would be if they terminated their policies.

Retirement Funds: This is an important area and most surveys want to include questions to assess the adequacy of the financial provision individuals have made for their retirement. However, the nature of pensions provision, and therefore, how one would judge its adequacy for an individual. The demographic profiles for those who considered personal savings / continuing to work / financial support from family or children as the main sources of funds for their retirement are summarized in the following table. A small minority about $14 \%$ of self employed had no plans for their retirement funds and will only decide what to do when they retire. Respondent's response more than one option of their sources of retirement. 
All respondents were asked to name their 3 most important sources of funds for their retirement. A majority of about $57 \%$ of employed and $65 \%$ of self employed respondents considered their personal savings and about $7 \%$ of employed will be depending on their insurance payouts to cover their retirement needs. Other sources of retirement funds include working after retirement is $21.42 \%$ and 28.57 respectively, $28 \%$ of employed and $14 \%$ of self employed relying on financial support from their family or children, funds from investments 35.71 and 57.14 and no any respondents mention the option downgrading to a smaller home to obtain cash.

Calculation of Retirement Funds: A fund established by an employer to facilitate and organize the investment of employees' retirement funds contributed by the employer and employees. The pension fund is a common asset pool meant to generate stable growth over the long term, and provide pensions for employees when they reach the end of their working years and commence retirement.

Among all the respondents excluding age below 30, only $14.28 \%$ of employed indicated that they have attempted to calculate how much they would need when they retire. Working married and retirees tended to calculate how much they would need when they retire, while working singles, unemployed and those with low income tended not to.

Amount of Retirement Fund Needed: Among those who said they had attempted to calculate or not how much they would need when they retire, $28.57 \%$ of employed and 64.28 of self employed felt that they would need about half of what they were earning at the point of retirement. $42.85 \%$ of employed and $14.28 \%$ of self employed thought that they needed at least $2 / 3$ of what they were earning at the point of retirement while about $7 \%$ of both profile felt that they needed $1 / 3$ or less of what they were earning at the point of retirement. Around $15 \%$ of the both categories tended to think that they needed at least two-thirds of what they earned at the point of retirement, while very small number of respondents tended to think they needed less.

\subsection{Investments}

Investment is putting money into something with the expectation of gain that upon thorough analysis has a high degree of security for the principal amount, as well as security of return, within an expected period of time. This section covers a number of aspects of investment including reasons of investment not investment, factors consider while investment and monitoring investment performance.

Investment Pattern of Respondents: This section examines the investment patterns of 
profiles and what they know about investments. More than two-thirds of employed and all self employed respondents indicated that they do have different types of investments. Of those who had invested, $50 \%$ of both categories respondents had stocks investment. $25 \%$ of employed and $100 \%$ of self employed respondents had their own business, $40 \%$ of employed and $50 \%$ of self employed who had invested they had property investments (excluding the property they were currently living in), and also more than $50 \%$ of employed and about $14 \%$ of self employed respondents had bank fixed deposit. Very negligible proportion of both categories invested in bond and other types of instrument. Those who invested tended to be working married, working parents, and pre- retirees.

Reasons for not Investing: When asked both who had investment or not, why they did not invest, more than $50 \%$ of both categories responded that they had insufficient funds. About 30\% of employed were not interested in investing while about $14 \%$ of both profile thought that investments were too risky. Other reasons cited include not knowing enough about investments $(7.14 \%)$ of both and no time to monitor their investments $14.28 \% \& 28.56 \%$ respectively.

The respondents who cited insufficient funds tended to be those whose household income were less than Rs. 200000 or whose emergency funds were less than 3 times of their monthly income. Those who felt that they did not know enough about investments scored lower in their knowledge of investments as compared to those who invested.

Reasons for Investing: Among those who invested, more than $50 \%$ did so in order to earn a higher rate of return for their spare cash or idle pension funds. Just around $15 \%$ of the participant took a more structured approach and did it as part of their retirement planning. Unlike financial planning where around $40 \%$ invested their ideal fund because s/he was recommended by a friend or relative, No one cited invested due to recommendations by financial advisor.

Factors Considered When Investing: When asked what factors they considered when investing, more than $75 \%$ of those who invested cited potential returns from the investment in both profile, $90 \%$ of employed and around $42 \%$ of self employed followed by risk of the investment, $50 \%$ of the employed and around $35 \%$ of the total respondents in different categories consider the amount of the investment, and around $29 \%$ cited about the period of the investment. Less than one-third $3 \& 4$ respectively considered whether the investment would meet their overall financial objectives, with around $33 \%$ of employed and $40 \%$ of self employed who invested their fund citing the fees and charges to be incurred and $42.85 \%$ of employed and $50 \%$ of self employed mentioning the economic climate. 
Monitoring of Investment Performance: $60 \%$ of employed and $78.57 \%$ of self employed those who invested mentioned that they regularly monitored their investments which is being represented in the following figure too.

Methods of Monitoring Investment Performance: Those who regularly monitored their investments, More than $80 \%$ of employed and more than $45 \%$ of self employed monitored by reading the monthly statements sent to them, around $66 \%$ of employed and $36 \%$ of self employed applied the method of monitoring the price of their investments against target price. Around one-third of both profile respondents monitor their investment by updating themselves by reading the financial news. $10 \%$ of employed profile respondents those who invested would depend on their stockbroker / financial adviser / bank branch teller while $20 \%$ of employed and less than $10 \%$ of self employed respondents actively ensured that they diversified their portfolios to have a good spread of investments with different risks.

\section{Major Findings of the Study}

The survey has assessed the awareness and attitudes of Nepalese towards basic money management, financial planning and investments. Some of the positive and negative financial behaviors which researcher has found while doing this research work.

Saving Pattern \& Loan decisions: Respondents generally displayed some good money management habits like $92.85 \%$ self employed and $100 \%$ employed indicated that they save. About a third (35.71\%) of employed and more than half of the self employed respondents $(57.12 \%)$ had the practice of saving a fixed amount of money from their monthly salaries, before spending the balance. while $57.12 \%$ of employed and $42.85 \%$ of self employed Pokherali said they pay for their expenses first, before saving the rest. 9 (64.28\%) of employed and $14(50 \%)$ of self employed keep track of how much they spend by monitoring the balance in their bank accounts or tracking their bills. (37.5\%) of employed and $14(53.33 \%)$ of self employed work out how much they can afford to borrow, before applying for a loan.

Financial Planning: Respondents recognize the importance of planning for their finances and have taken some basic steps in financial planning. More than $50 \%$ of the both categories have mentioned some basic financial planning. This includes setting aside savings for their future, having a retirement plan, buying insurance policies to provide for unexpected events, and investing to grow their wealth.

Considered the Risks of Investments \& Monitoring: Respondents those who invested, take a considered approach in their investment decisions. Around 33\% of employed 
and $40 \%$ of self employed of those who invested considered the risks involved before investing. $60 \%$ of employed and $78.57 \%$ of self employed those who invested monitored their investments.

Knew Basic Features of Loans: Respondents are generally knowledgeable about their loans. Not more than $76 \%$ are aware of the basic features of their loans (which banks they borrowed from, amount of monthly installments, loan repayment period, amount of loan outstanding and interest rate charged). $35.71 \%$ of employed and 28.57 of self employed understood that rolling over their unsecured loan could lead to interest being charged on the outstanding balance and other compounded penalties.

Understood Risks \& Portfolio: The respondents who invested generally understand the risks inherent in investments and the importance of diversification. More than $50 \%$ of both categories, of those who invested understood that any investment which promises higher returns usually carries higher risks. Around 50\% of those who invested knew that a welldiversified portfolio was one that spread risks over different investments and / or industry sectors.

Savings for Emergencies \& Retirement: While respondents generally set aside savings, many do not appear to have put aside sufficient funds for emergencies. Only some respondents shave cash savings of their monthly income. Many Pokhareli do not appear to have a plan to meet their retirement needs. While the majority of Pokherali consider personal savings and pension to be their most important source of retirement funds, less than $30 \%$ of both categories have actually calculated how much they would need when they retire. For those who have made calculations, below 15\% think that they will need twothirds or more of what they had earned at the point of retirement. It is widely recognized that a person will need two -thirds or more of his last drawn monthly pay when he retires in order to have a comfortable retirement.

Insurance Policies: Large proportion of both Categories did not know that the general feature of their insurance policy. Only 33\% of respondents were aware of what would happen if they could not afford their premiums or if they stopped paying their premiums temporarily. An even lesser proportion (around 14\%) knew what the penalty fees and charges would be if they terminated their policies.

\section{Discussion and Conclusion}

The purpose of this study was to find out the understanding of personal financial knowledge among respondent and the potential relationship between financial knowledge 
and their daily financial behavior. This study attempts to make an original contribution in these areas by surveying 56 Employed and Self Employed in Pokhara Nepal. The main finding is that the surveyed personal finance topics are important and respondents are not well knowledgeable about it. First, the results show that planning is very important. Additionally, many long-term financial planning issues such as setting goals and issues related to Personal benefit provisions are important. First, this study attempts to identify what are important questions in personal finance that people must know. Second, by identifying the importance and weaknesses in people's personal finance knowledge, we can more effectively develop educational programs to correct the deficiencies. Based on the findings, following discussion and conclusion have been drawn.

- When deciding on whether to purchase a financial product, $42.85 \%$ of employed and $35.71 \%$ respondents relied on the recommendations of their friends or relatives. $28.57 \%$ of employed and $42.86 \%$ self employed respondents them did their own comparisons among similar financial products but no any takes advices from financial advisor (experts) it indicates that Pokherali person or household are managing their personal finance old method.

- Majority of the respondents indicated that they had some form of savings in the bank, including either a savings or current account and also most of the respondents have habit of saving fixed amount before spending. Those who saved a fixed amount of money from their monthly salaries tended to agree with the attitude statement "I should save first, before spending the balance". Only few respondents of employed category spend all the money what they earned. Definitely it addresses their consciousness about saving.

- Cost is one of the most important components of personal finance, majority of both categories of respondents were cited that they use their own saving to buy durable product. Around $50 \%$ of the both categories of respondents were tracking their expenditure. However very negligible proportion of self employed respondents was considering the affordability before borrowing or applying for loan. It can be conclude that most of the pokherali are unaware about the facilities of loan and method of cost efficiency, also almost all the respondents have very weak planning before financial decision.

- Financial plan is the backbone of each and every financial decision; some of the respondents well understand about the financial planning and have taken some basic 
steps in financial planning. More than $50 \%$ of the both categories have mentioned that some basic financial planning. This includes setting aside savings for future, having a retirement plan, buying insurance policies to provide for unexpected events, and investing to grow their wealth.

- Most of the respondents those who have financial planning had started financial planning very late like after marriage or many years after marriage; although almost all indicated that it was important to start early. It seems that most of the respondents plan for emergencies and good return in investment. Those who doesn't have plan most of them cited the main cause was 'too many uncertainties no point to plan' 'not enough money' and their pension and saving is enough'.

- About $28 \%$ of employed and about $14 \%$ of self employed responded that they had approached professional advisors to help them manage their finances and one-third (33\%) of self employed those who approached professional advisers did so because the advisor (experts) was a friend / relative. $50 \%$ of employed and $66 \%$ of self employed had sought professional advice because they felt that they would be getting advice from an expert. Respondents those who were not approaching professional advice they argue the cause are they can make their own decision, not enough money and uncomfortable to disclosing financial matter. it shows response clarifies the weakness of planning in respondent and traditional concept of managing their finance. In Nepal it is very hard to find the expert and expert are also not starting such counseling professionally, that might be the reason most of the respondents doesn't have well concept and importance of planning.

- It is found that more than $50 \%$ of the both categories respondents have life insurance and while $79 \%$ of employed and $86 \%$ of self employed have some form of general insurance for their car or home. Very few respondents about 50\% who had life insurance knew the key features of their insurance policies such as the company they bought the policy from, the amount of premiums, what the policy covers, the amount of payout and whether the bonus payouts. Only few less than $33 \%$ of respondents were aware of what would happen if they could not afford their premiums or if they stopped paying their premiums temporarily, eve only about $15 \%$ respondents have knowledge about the penalties and fees. It can be concluded that the trend of buying insurance policy is significantly increasing but the knowledge and awareness about the reality about insurance policy is very low.

- It is widely recognized that a person will need two -thirds or more of his last drawn monthly pay when he retires in order to have a comfortable retirement. A majority 
of about $57 \%$ of employed and $65 \%$ of self employed respondents considered their personal savings and 35.71percent and 57.14 define the source of funds from their investments after retirement. From these points it is obvious that all the respondents are worried about their retirement but even now they are not getting the trustworthy method to secure their retirement. Hardly, $14.28 \%$ of employed and same percentage of self employed thought that they needed at least $2 / 3$ of what they were earning at the point of retirement. It also stresses the point of knowledge of calculating the fund requirement for retirement.

- According to the different in nature and characteristic respondents the pattern of investment is quite different in both categories. One category of respondents is drawn from the self employed and obdurately all of them have their own business and their major investment is in their own business. However, according to continuously development of corporate body like banking, insurance, telecommunication, hydropower etc purchasing the share of company also became fashion. Hence, majority of both categories of respondents invested in stock. There might be the lack of risk awareness/knowledge both profile respondents invested in risky assets rather than bond.

- Majority of the respondents who were not invested they cited that 'no money to invest, 'no time to monitor investment' etc. and also some are afraid of risk associated investment. But, about $30 \%$ of employed respondents had mentioned that they were not interested in investing. In short we can conclude most of the respondents don't have the basic knowledge about the investment.However, those who are invested among them $50 \%$ of both group quoted the cause behind investment is in order to earn a higher rate of return for their spare cash or idle pension funds.

- Unlikely around $40 \%$ invested their ideal fund because s/he was recommended by a friend or relative. Similarly, most of the respondents of both group invested their funds to get higher return rather than fulfill their financial plan and maintain the portfolio. Vary negligible proportion of investor considered the risk associated with before investing, economy climate and investment objectives. Such type of reaction of respondents clarifies that pokherali investor invest their fund in ad-hock basis in spite of planning and setting objective. In case of monitoring the investment self employed respondents are quite more conscious i.e. $60 \%$ of employed and $78.57 \%$ of self employed those who invested monitored their investments.

- Among the investor who regularly monitor the investment performance More than $80 \%$ 
of employed and more than $45 \%$ of self employed monitored by reading the monthly statements sent to them, around $66 \%$ of employed and $36 \%$ of self employed applied the method of monitoring the price of their investments against target price. But there is considerable no. of investor who would depend on their stockbroker / relatives / bank branch teller etc. Only $20 \%$ of employed and less than $10 \%$ of self employed respondents actively ensured that they diversified their portfolios to have a good spread of investments with different risks. To invest is not enough but monitoring the investment tactfully is most to achieve target. Hence it is noticeable that quantitatively the trend of investment is increasing day by day but monitoring is very weak due to the lack of awareness and lack of education.

\section{REFERENCES}

Bell, M. (2005 Mar). A matter of no small interests: Real short-term interest rates and inflation since the 1990s. Speech Monetary Policy Committee (MPC) to the Institute of Directors and Milton Keynes Chambers of Commerce at Cranfield University.

Bridges, S., \& Disney, R. (2004). Use of credit arrears on debt among low income families in the United Kingdom. Fiscal Studies, 25(1): 1-25.

Brown, S., Taylor, K., \& Price, S.W. (2005). Debt and distress: Evaluating the psychological cost of credit. Journal of Economic Psychology, 26: 642-3.

Debelle, G. (2004 Mar). Household debt and the macroeconomy. BIS Quarterly Review, 51-64.

Del-Rio, A., \& Young, G. (2005). The determinants of unsecured borrowing: Evidence from the British household panel survey. Working paper 263. London: Bank of England.

Department of Trade \& Industry (DTI) (2004). Tackling over-indebtedness: Action plan 2004, [online]. Available: http://www.berr.gov.uk/files/ file18559.pdf. (2008, February 7).

Department of Trade \& Industry (DTI) (2005). Over-indebtedness in Britain: A DTI report on the MORI financial services survey 2004, [online]. Available: www.berr.gov.uk/ files/ file18550.pdf(2008, February 7).

Furnham, A., \&Argle, M. (1998). The psychology of money. London: Routledge.

Gross, D.B., \& Souleles, N.S. (2002). Do liquidity constraints and interest rates matter for consumer behavior? Evidence from credit card data. The Quarterly Journal of Economics, 117:149-85.

Kempson, E. (2001). Select committee on social security, minutes of evidence, memorandum submitted by Elaine Kempson, Bristol, Personal Finance Research Centre, University of Bristol (SF 41).

Kempson, E., McKay, S., \& Willitts, M. (2004). Characteristics of families in debt and the nature of indebtedness. Research report No. 211, London: Department for Work and Pensions.

Kwok, H., Milevsky, M., \& Robinson, C. (1994). Asset allocation, life expectancy, and shortfall. Financial Services Review, 3(2):109-126.

Lury, C. (2004). Everyday life and the economy. in Bennett, T and Watson, D (eds). Understanding Everyday Life. Oxford: Blackwell. 
May, Q., Tudela, M., \& Young, G. (2004). British household indebtedness and financial stress: A householdlevel picture. Bank of England Quarterly Bulletin, Winter: 414-28.

Office of Fair Trading (OFT) (2005). Money and credit-Tips on debt, [online]. Available: www.oft.gov.uk/ consumer/money/ tips.htm (2005, December 19)

Oxera. (2004). Are UK households over-indebted? Oxford: Oxford Economic Research Associates.

The Guardian Staff Writer (2004). Landmark ruling as judge erases couple's debt. The Guardian, [online]. Available: http://money.guardian.co.uk/creditanddebt/debt/story/0,1456,1338330,00.html (2008, February 7).

The Guardian Staff Writer (2005). Court cancels debt that grew from $£ 6,000$ to $£ 380,000$. The Guardian, [online]. Available: http://money.guardian.co.uk/creditanddebt/story/0,1456,1537662,00.html (2008, February 7).

Tudela, M., \& Young, G. (2005). The determinants of household debt and balance sheets in the United Kingdom. Working paper No. 266. London: Bank of England.

UK Parliament. (2003). Report published on transparency of credit card charges, treasury committee press notices, [online]. Parliamentary committees (2008, February 7). 